\title{
An Empirical Comparison of Insider Trading Enforcement in Canada and the United States
}

\author{
Anita Anand \\ University of Toronto, Faculty of Law \\ Stephen J. Choi \\ New York University School of Law \\ Adam C. Pritchard \\ University of Michigan Law School \\ Poonam Puri \\ Osgoode Hall Law School of York University, ppuri@osgoode.yorku.ca
}

\section{Source Publication:}

57 International Review of Law and Economics 49 (2019)

Follow this and additional works at: https://digitalcommons.osgoode.yorku.ca/scholarly_works

Part of the Antitrust and Trade Regulation Commons

\section{Repository Citation}

Anand, Anita; Choi, Stephen J.; Pritchard, Adam C.; and Puri, Poonam, "An Empirical Comparison of Insider Trading Enforcement in Canada and the United States" (2019). Articles \& Book Chapters. 2746.

https://digitalcommons.osgoode.yorku.ca/scholarly_works/2746

This Article is brought to you for free and open access by the Faculty Scholarship at Osgoode Digital Commons. It has been accepted for inclusion in Articles \& Book Chapters by an authorized administrator of Osgoode Digital Commons. 


\title{
An Empirical Comparison of Insider Trading Enforcement in Canada and the United States
}

\author{
Anita Anand, Stephen J . Choi, A.C. Pritchard \& Poonam Puri*
}

19 October 2018

* J .R. Kimber Chair in Investor Protection and Corporate Governance, Faculty of Law, University of Toronto; Murray and Kathleen Bring Professor of Law, New York University School of Law; Frances and George Skestos Professor of Law, University of Michigan Law School; and Professor of Law, Osgoode Hall Law School, respectively. We thank the following for useful comments on earlier drafts: participants at the Enforcement of Securities Law Violations Roundtable sponsored by the Law Foundation of Ontario and the University of Toronto; the Canadian Law and Economics Association, the American Law and Economics Association and the Conference on Empirical Legal Studies annual meetings. We are grateful to Matthew Brown, Ankita Gupta, J ason Lamb, Ekin Ober, Aarushi Puri, and Chris Puskas for invaluable research assistance funded in part by the Law Foundation of Ontario. The support of the Social Sciences and Humanities Research Council of Canada (SSHRC Insight Grant 435-2013-2169) is also gratefully acknowledged. 


\begin{abstract}
Canadian and American securities market regulators have differing approaches to enforcement. In this article, we present the results of an empirical study comparing a highly salient aspect of securities enforcement-insider trading -in Canada and the United States. We reach a number of important findings. First, adjusting for trading volume, Canada has a greater intensity of enforcement when compared to the U.S. Second, Canadian securities regulators primarily concern themselves with insider trading in Canadian companies, while the SEC brings more enforcement actions involving insider trading in companies incorporated outside the U.S. Third, we do not find significant differences in the fraction of actions involving multiple traded companies between Canada and the U.S. However, we do see that U.S. investigations involve a significantly greater number of defendants and that the SEC is more than twice as likely to pursue tippers or tippees (although we observe no significant difference in the likelihood that top insiders will be pursued). Fourth, we find that U.S. cases are significantly more likely to result in a criminal referral leading to prosecution. Fifth, we find that settlements are more likely in the U.S. Finally, in terms of monetary penalties, we find no significant difference between the two countries. However, we do find that Canada is more likely to apply a bar as a sanction, but if a bar is applied, the U.S. is more likely to make the bar permanent. These findings neither demonstrate a need for systemic reform in either jurisdiction nor suggest that centralized regulation is necessarily better from an enforcement perspective. But, they do provide insight into the differing points of regulatory emphasis in two jurisdictions. From a comparative perspective, our research thus allows securities regulators to begin to evaluate whether their enforcement approach is optimal on the basis of quantitative data.
\end{abstract}




\section{Introduction}

The securities markets of Canada and the United States are closely integrated. A significant number of public companies are listed on stock exchanges in both countries, encouraged by coordinated disclosure and offering requirements that facilitate capital raising on both sides of the border. One aspect of securities regulation, however, remains largely distinct: enforcement. Although provincial securities regulators in Canada have entered into memoranda of understanding with the U.S. Securities and Exchange Commission (SEC) to facilitate investigations involving conduct in both countries, the enforcement regimes remain separate. ${ }^{1}$ Moreover, the two countries have different regulatory structures, with provincial and territorial securities commissions playing the principal role in Canada, whereas the SEC overshadows state securities regulators in the U.S. These differences in regulatory structure invite a comparison of the two approaches. Moreover, there is a long-standing and lively debate in Canada over whether to move to a national or "cooperative" regulator, modeled to some extent on the SEC. This debate, however, suffers from a dearth of empirical evidence comparing the two alternative regulatory models. $^{2}$

In this article, we present the results of an empirical study comparing a highly salient aspect of securities enforcementinsider trading - in Canada and the U.S. The SEC has greater resources, greater economies of scale, and more experience in bringing insider trading actions. These factors suggest that the SEC will have the capacity to bring more insider trading actions than its Canadian counterparts. In order to test this and related hypotheses, we identified insider trading enforcement actions brought by provincial securities regulators in Canada and the SEC in the U.S. from 2005 to 2015. For these actions, we collected data on industry, number and type of defendants, time to resolution, and sanctions imposed. Our data are crosssectional in nature and thus, our findings are largely based on correlations. Nonetheless, we believe that our findings mark a

\footnotetext{
${ }^{1}$ Enforcement within Canada can differ among Canadian provinces and territories. We take this point into account in our empirical analysis.

${ }^{2}$ See generally, for a comparison of public and private enforcement in Canada and the U.S., Poonam Puri, "Securities Litigation and Enforcement" (2012) 37:3 BrookJ Int L 967.
} 
first step in assessing differences and similarities in Canadian and U.S. insider trading enforcement.

We find, unsurprisingly, that the number of actions is much larger in the U.S., reflecting its larger economy and the size of its capital markets. But when we examine the numbers relative to the amount of trading, the intensity of enforcement in Canada looks considerably greater, inconsistent with our hypothesis that the SEC will bring its greater resources to bear in pursuing insider trading cases. However, Canadian securities regulators primarily concern themselves with insider trading in Canadian companies, while the SEC brings more enforcement actions involving insider trading against foreign incorporated companies listed in the U.S.

This article contributes to the developing body of empirical scholarship studying enforcement actions in securities regulation. Much of the existing literature focuses solely on the U.S., including studies on: the interaction between public and private enforcement; ${ }^{3}$ the role of scandals and other forms of public pressure on enforcement decisions at the SEC; 4 the SEC's choice between enforcement in civil court or before an SEC administrative law judge; ${ }^{5}$ the incentives of SEC enforcement attorneys; ${ }^{6}$ the accuracy of enforcement statistics put forth by the SEC; 7 the role of lead plaintiffs and plaintiffs' attorneys in shareholder litigation; ${ }^{8}$ the characteristics of securities class

${ }^{3}$ See Stephen J Choi \&A C Pritchard, "SEC Investigations and Securities Class Actions: An Empirical Comparison" (2016) 13:1J Empirical Leg Stud 27.

${ }^{4}$ See Stephen J Choi, A C Pritchard \& Anat Carmy Wiechman, "Scandal Enforcement at the SEC: The Arc of the Option Backdating Investigations" (2013) 15:2 Am L \& Econ Rev 542.

5 See Stephen J Choi \&A C Pritchard, "The SEC's Shift to Administrative Proceedings: An Empirical Assessment” (2017) 34:1Yale J Reg 1.

${ }^{6}$ See Ed deHaan, Simi Kedia, Kevin Koh, \& Shivaram Rajgopal, "The Revolving Door and the SEC's Enforcement Outcomes: Initial Evidence from Civil Litigation" (2015) 60: 2-3J Acc \&Econ 65.

${ }^{7}$ See Urska Velikonja, "Reporting Agency Performance: Behind the SEC's Enforcement Statistics" (2016) 101:4 Cornell Law Review 901.

${ }^{8}$ See Stephen J Choi, J essica Erickson \&Adam Pritchard, "Frequent Filers: Repeat Plaintiffs in Shareholder Litigation (U.S. Chamber Institute for Legal Reform September 2013); Stephen J Choi, Drew Skinner \&A C Pritchard, "The Price of Pay for Play in Securities Class Actions" (2011) 8:4 J Empirical Leg Stud 650; Stephen J Choi, "Motions for Lead Plaintiff in Securities Class Actions" (2011) 40:1J ournal of Legal Studies 205; Stephen J Choi \& Robert Thompson, "Securities Litigation and its Lawyers: Changes During the First Decade After the PSLRA" (2006) 106:7 Colum L Rev 1489. 
actions against bankrupt companies; ${ }^{9}$ the role of auditors in settlements and securities class actions; ${ }^{10}$ and the presence of frivolous lawsuits and the impact of reforms to combat such lawsuits. ${ }^{11}$ Missing from this literature, however, is a comparative analysis of enforcement across borders. This study offers a unique contribution in this regard, providing original data from the SEC and provincial securities commissions in Canada.

We proceed as follows. Part 2 provides background on the regulatory regimes in Canada and the U.S., with specific reference to insider trading. Part 3 develops our hypotheses. Part 4 presents the results of our empirical tests. Part 5 offers analysis of the results and concluding thoughts on the policy implications of differing approaches to securities regulation in Canada and the U.S.

\section{Background}

\section{A. Canada}

Canada does not have a national securities regulator; in the U.S., by contrast, the principal securities laws are federally enacted and enforced by the SEC.12 Securities laws, including insider trading laws, are enacted and enforced at the provincial and territorial levels. However, insider trading law is generally consistent across Canadian provincial and territorial jurisdictions. The modern justification for insider trading laws in Canada comes from the 1965 Kimber Report, which asserted that all investors (insiders and outsiders alike) should be able to

9 See J ames J Park, "Securities Class Actions and Bankrupt Companies"

(2013) 111:4 Mich L Rev 547.

10 See J ames J Park, "Auditor Settlements of Securities Class Actions" (2017)

14:1J Empirical Leg Stud 169.

${ }^{11}$ Stephen J Choi \&A C Pritchard, "The Supreme Court's Impact on Securities Class Actions: An Empirical Assessment of Tellabs" (2012) 28:4 J L, Econ, \& Org 850; Stephen J Choi, Karen Nelson \&A C Pritchard, "The Screening Effect of the Private Securities Litigation Reform Act" (2009) 6:1J Empirical Leg Stud 35; Stephen J Choi, "Do the Merits Matter Less After the Private Securities Litigation Reform Act" (2007) 23:3 J L Econ \& Org 598; Marilyn FJ ohnson, Karen K Nelson \& A C Pritchard, "Do the Merits Matter More? The Impact of the Private Securities Litigation Reform Act" (2007) 23:3J L, Econ \& Org 652; Stephen J Choi, J ill E Fisch \&A C Pritchard, "Do Institutions Matter? The Impact of the Lead Plaintiff Provision of the Private Securities Litigation Reform Act, (2005) 83:4 Wash ULQ 869; Stephen J Choi \&J ames Bohn, "Fraud in the New-Issues Market: Empirical Evidence on Securities Class Actions" (1996) 144:3 U Penn L Rev 903.

12 Reference Re Securities Act, 2011 SCC 66, [2011] 3 S.C.R. 837. 
participate in the capital markets on a level playing field and therefore insider trading should be prohibited. ${ }^{13}$ Following the Kimber Report, the Ontario Securities Act of 1966 introduced the first substantial regulation of insider trading in Canada. ${ }^{14}$

Unlike the U.S., the basic rules on insider trading in Canada are set forth in statute. ${ }^{15}$ Insiders are defined as directors or officers of the reporting issuer or subsidiaries of the reporting issuer. ${ }^{16}$ In addition, any person or company that has a direct or indirect beneficial ownership of, or control or direction over, more than 10 per cent of the reporting issuer's voting securities, is also an insider. ${ }^{17}$ Provincial securities commissions also have broad discretion to designate a person or company as an insider, if doing so would be in the public interest. ${ }^{18}$ Insiders may purchase or sell securities, provided that their trades are not based on undisclosed (non-public) material information and are reported within five days from the date of the trade (National Instrument 55-104). Insider reports are typically filed online through the "System for Electronic Disclosure by Insiders"

13 The Kimber, chaired by J ohn R Kimber, Q.C., Report of the Attorney General's Committee on Securities Legislation in Ontario (Toronto: Queen's Printer, 1965) at 10. Case law continues to evidence a commitment to this concern. For example, in In the Matter of M.C.J .C Holdings Inc. and Michael Cowpland [2002] 25 OSCB 1133, an OSC panel used its public interest jurisdiction to reject a settlement with an insider trader because there was no assurance that the conduct would not occur again and a concern that the settlement agreement would not sufficiently deter others from committing insider trading. The lack of deterrence was particularly important to the panel, as it felt that "illegal insider trading by its very nature is a cancer that erodes public confidence in the capital markets" and therefore must be sufficiently punished.

14 David J ohnston, Kathleen Rockwell \& Cristie Ford, Canadian Securities Regulation (Markham: LexisNexis Canada, 2014) at 339.

${ }^{15}$ See for example Securities Act (Ontario), RSO ss 107, 76 (1990) [OSA]. 16 Directors and officers are defined in such a way so as to include people who lack the formal title but act in the capacity of a director or officer. See for example: Securities Act, RSA 2000, c S-4, s.1(o), Securities Act, RSBC 1996, c 418, s 1(1); Securities Act, RSO 1990, c S.5, s 1(1).

${ }_{17}$ Securities Act, RSA 2000, c S-4, s 1(aa); Securities Act, RSBC 1996, c 418, s 1(1)("insider); Securities Act, CCSM c S50, s 1(1) ("insider"); Securities Act, SNB 2004, c S-5.5, s 1(1) ("insider"); Securities Act, RSNL 1990, c S-13, s 2(1)(s); Securities Act, RSNS 1989, c 418, s 2(1)(r); Securities Act, RSO 1990, c S 5, s 1(1)("insider"); Securities Act, RSPEI 1988, c S-3.1, s 1(z); Securities Act, RSQ, c v-1.1, s 89.

18 Securities Act, RSA 2000, c S-4, ss 1 (aa) “Insider" (v), 10(1)(c); Securities Act, RSBC 1996, c 418, ss 1(1) "insider" (e), 3.2(a); Securities Act, RSO 1990, c S ss 1(1), 1(11). 
(SEDI). ${ }^{19}$

In addition to insiders, provincial securities statutes regulate the conduct of those in a "special relationship" with the reporting issuer. The relevant legal provision states that "No person or company in a special relationship with a reporting issuer shall purchase or sell securities of the reporting issuer with the knowledge of a material fact or material change with respect to the reporting issuer that has not been generally disclosed."20 The term "special relationship" includes but is not limited to insiders and covers a wide group of individuals such as: a person that is an insider, affiliate or associate of a person or company that is proposing to make a take-over bid of the issuer or enter into a business combination with the issuer; a person or company that has engaged in or is proposing to engage in any business or professional activity on behalf of the issuer; a person or company that learned of the non-public material information with respect to the issuer while they were in any of the foregoing positions; and a person that learns of the non-public material information from anyone else in a special relationship with the reporting issuer and knows or ought to reasonably have known that the other person was in such a special relationship. ${ }^{21}$

The definition of "special relationship" is at the core of the prohibition on insider trading. ${ }^{22}$ Tipping, defined as informing any other person of a material fact or material change that is not generally disclosed other than in the necessary course of business, is also prohibited under the statute. ${ }^{23}$ With regards to both illegal insider trading and tipping, the definition of "special relationship" is of crucial importance as it means that the class of persons potentially liable for insider trading extends beyond

19 System for Electronic Disclosure by Insiders, OSC NI 55- 102 - 24 OSCB 6325 and 26 OSCB 3163.

20 OSA, supra note 15 at. § 76(1).

21 Securities Act, RSA 2000, c S-4, s 9; Securities Act, RSBC 1996, c 418, s 3; Securities Act, CCSM c S50, s 112(1); Securities Act, SNB. 2004, c S-5.5, s 147(1); Securities Act, RSNL 1990, c S-13, s 77(5); Securities Act, RSNS 1989, c 418, s 82(5); Securities Act, RSO 1990, c S.5, s 76(5); Securities Act, RSPEI. 1988, c S-3.1, s 12(1); Securities Act, 1988, ss 1988-89, c S-42.2, s 85(1); Securities Act, SNWT 2008, c 10, s 12(1); Securities Act, S Nu 2008, c 12, s 12(1); Securities Act, SY 2007, c 16, s 12(1).

22 Securities Act, RSA 2000, c S-4, s 207(1); Securities Act, RSBC 1996, c 418, ss 57.2, 136, 136.2; Securities Act, RSO 1990, c S.5, s 134(1); Securities Act, RSPEI. 1988, c S-3.1, ss 119(1), 155(1); Securities Act, RSQ, c V-1.1, ss 187, 226; Securities Act, S Nu 2008, c 12, ss 119(1), 155(1); Securities Act, RSNS 1989, c 418, s 142(1).

23 Ibid. § 76(2). 
those who are defined as "insiders" in the statute. ${ }^{24}$ For example, since tippees are themselves considered to be in a special relationship with an issuer, material information used in a trade may be third or fourth hand and still be subject to the prohibition, demonstrating the wide scope of the "special relationship" definition. ${ }^{25}$

The test for materiality is codified in statute. A material fact is defined as "a fact that would reasonably be expected to have a significant effect on the market price or value of the securities," 26 while a material change is defined as "a change in the business, operations or capital of the issuer that would reasonably be expected to have a significant effect on the market price or value of [any of the issuer's securities]."27 This statutory test is objective and requires courts to view materiality from the perspective of the trading markets. ${ }^{28}$ More recently in Cornish v Ontario Securities Commission (OSC), the OSC affirmed that the test for materiality is objective and stressed that the test is highly contextual and therefore void of any "bright line" rules. ${ }^{29}$

For disclosure, courts have interpreted this requirement as requiring wide dissemination "in a manner calculated to effectively reach the marketplace" and in such a way so as to give "public investors [a] reasonable amount of time to analyze the information." 30 Unlike the materiality requirement, there have not been many recent cases clarifying what constitutes a reasonable time for the purposes of dissemination. A leading case remains Re Harold P. Conner, where the OSC developed a twopronged test for determining when information is generally disclosed: the information was generally disseminated to the public; and, the public was given sufficient time to consider the information given its nature and complexity. ${ }^{31}$ There is no firm

24 Ibid. § 76(5).

25 Disclosure Standards, OSC, NP 51-201 (12 J uly 2002), online:

$<$ http:// www.osc.gov.on.ca/ documents/ en/ Securities-

Category5/pol_20020712_51-201.pdf>at s 3.2(2), (3).

${ }^{26}$ Securities Act, RSO 1990, c S.5, s 1(1) ("material fact").

27 Ibid., ("material change").

${ }^{28}$ YBM Magnex International Inc., Re, [2003] 26 OSCB 5285 at para 91, 2003 CarswellOnt 2632.

29 Cornish v Ontario (Securities Commission) 2013 ONSC 1310 at para 51-

53, 227 ACWS (3d) 276. See also Rex Diamond Mining Corp v Ontario

(Securities Commission), 2010 ONSC 3926, 191ACWS (3d) 998; Donald, Re

[2013], 2013 CarswellOnt 936, 26 OSCB 1449; Kapusta, Re[2011] ABASC

322.

30 NP 51-201, supra note 25 , s 3.5(2).

31 In the Matter of Harold P Conner et al, [1976] OSCB 149 at 174. 
rule as to when this will occur, since what is a reasonable time for investors to analyze the information depends on a number of factors such as the nature and complexity of the information, the nature of the market in which the securities are being traded, and the manner in which the information is released. ${ }^{32}$

There are various defenses to insider trading. These include acting without using the information, ${ }^{33}$ no knowledge of the material information, ${ }^{34}$ disclosure of a material fact or material change in the necessary course of business before it has been generally disclosed, ${ }^{35}$ and reasonably believing that the undisclosed material fact or change had been generally disclosed prior to the impugned trade or that the other party to the transaction had knowledge of the undisclosed material information. ${ }^{36}$ In addition, insiders can enter into automatic securities disposition plans whereby the insider can delegate selling authority to a broker. As long as the plan eliminates the insider's discretion over sales made pursuant to the plan, the

32 NP 51-201, supra note 25.

33 Securities Act, RSA 2000, c S-4, s 147(5)(b); Securities Act, RSBC 1996, c 418, s 57.4(4); Securities Act, CQLR, c V-1.1, ss 187(2)-(3).

34 Guidelines for Policies and Procedures Concerning Inside Information, OSCNP 33-601(1998).

35 Securities Act, RSA 2000, c S-4, s 147(4); Securities Act, RSBC 1996, c 418, s 57.2(3); Securities Act, CCSM c S 50, 112(3); Securities Act, SNB 2004, c S5.5, s 147(4); Securities Act, RSNL 1990, c S-13, s 77(2); Securities Act, RSNS 1989, c 418, s 82(2); Securities Act, RSO 1990, c S 5, s 76(2); Securities Act, RSPEI 1988, c S-3.1, s 155(2); Securities Act, 1988, S S 1988-89, c S-42.2, s 85(4).

36 OSA, supra note 15 at § 76(4); Securities Act, RSBC 1996, c 418, s 57.4(1); Securities Act, RSQ, c V-1.1, s 187; Securities Act, 1988, S S 1988-89, c S42.2, s 85(6); Securities Act, RSA 2000, c S-4, s 147(6); Securities Act, SY 2007, c 16, s 156(1); Securities Act, S Nu. 2008, c 12, s 156(1); General Securities Rules, N S Reg 201/87, s 181(5). A claim of honest but unreasonable belief is not a sufficient defense. In Gorrie, Re, 2006 ABASC 1087, at paras 5, 15-17, ASCD No 115, the Alberta Securities Commission accepted that the accused had a genuine belief that the information he obtained from a CEO had been generally disclosed at a recently held board meeting. Nevertheless, the commission held that the accused should have known the discussions were confidential and that he had a responsibility to confirm that this information had been generally disclosed before trading. Similarly, the Ontario Superior Court of J ustice in Finkelstein v Ontario (Securities Commission), 2016 ONSC 7508 at para 116-117,274 ACWS (3d) 656 recently affirmed that a number of objective contextual factors should be used to determine whether or not a person who receives material non-public information ought to have known that the source of the information was someone in a special relationship with the reporting issuer, regardless of their subjective belief. 
insider will have a defense to allegations of insider trading. ${ }^{37}$

In terms of penalties for insider trading, securities commission staff can choose to bring a quasi-criminal action which, if a conviction is obtained, could result in jail time of maximum five years less a day or a fine or both. In this case, the fine is equal to the greater of $\$ 5$ million, or the amount equal to triple the amount of the profit made or the loss avoided by the person or company by reason of the contravention. Alternatively, securities commission staff can bring an administrative action where the maximum fine is one million dollars per offence. 38 Other sanctions can be layered on top of this penalty in the case of an individual, including bans from trading or from serving as a director or officer of a public company. ${ }^{39}$

\section{B. United States}

Unlike Canadian law, the offense of insider trading in the U.S. is based nominally on the prohibition against fraud found in Rule 10b-5 of the Securities Exchange Act, 40 but it is closer to the truth to call it a species of common law. ${ }^{41}$ Beginning in the 1960s, the SEC pushed the courts to recognizeinsider trading as fraud. 42 The agency enjoyed considerable success with its agenda in the lower courts, most notably the Second Circuit, the leading intermediate court for securities law. ${ }^{43}$ The government got pushback, however, when the Department of J ustice ("DOJ") expanded the prohibition to include criminal enforcement, which brought the topic of insider trading to the attention of the Supreme Court of the United States. Beginning with Chiarella v United States, ${ }^{44}$ the Supreme Court narrowed the scope of

\footnotetext{
${ }^{37}$ Automatic Securities Disposition Plans and Automatic Securities Purchase Plans, OSC Staff Notice 55-701.

38 See, e.g., Section 122 OSA, supra note 35.

39 See, e.g., Section 127 OSA, supra note 35.

40 17 CFR § 240.10b-5 [Securities Exchange Act].

${ }^{41}$ There is a "short swing" profits provision for trades by statutory insiders under $\S 16(\mathrm{~b})$ of the Securities Exchange Act, but it has limited reach. Although it is a strict liability provision, it only applies to purchases and sales (or sales and then purchases) made within six months of each other. As such, it is both under- and over-inclusive, and more to the point, readily avoided by timing transactions. Rule 10b-5, which is tied to the insider's knowledge, is the more significant insider trading prohibition.

42 The beginning of the SEC's modern campaign against insider trading is usually traced to an administrative proceeding against a broker-dealer, Cady, Roberts \& Co., 40 SEC 907 (1961).

43 See, e.g., SEC v Texas Gulf Sulphur Co., 401 F 2d 833 (1968) (recognizing parity of information theory of insider trading under Rule 10b-5).

44445 US 222 (1980).
} 
insider trading under Rule 10b-5. The law of insider trading as it stands now in the U.S. incorporates two principal theories:

1) the classical theory, first recognized by the Supreme Court in Chiarella, which holds that a corporate insider (or temporary insider, such as a lawyer or an accountant) commits fraud when he trades with a shareholder without disclosing material, non-public information to that shareholder; and

2) the misappropriation theory, which holds that a person who has received material, non-public information is subject to a duty of trust and confidence, and commits fraud when he trades on the basis of that information without disclosing his intention to trade to the source of the information. ${ }^{45}$

A slightly broader prohibition applies to insider trading in connection with tender offers; under Rule 14e-3 of the Exchange Act, the government is not required to prove a breach of fiduciary duty in such cases. ${ }^{46}$ U.S. insider trading doctrine also includes a prohibition against tipping; tippees are barred from trading if they know or should know that they have received information from an insider who received a personal benefit from disclosing the information (such as cash, or an indirect benefit by making a gift of the information to a relative or friend). ${ }^{47}$ Tippers are jointly and severally liable with their tippees.

The common law character of the U.S. insider trading prohibition leads to a variety of gray areas around the edges of the rule. The SEC has resisted a statutory codification, worrying that a statute would create a "road-map to fraud" if not written expansively enough. ${ }^{48}$ Congress has generally acquiesced in the SEC's reluctance to reduce the insider trading prohibition to statute. Instead, the legislature has intervened only to correct particular problems with insider trading law, such as creating a private right of action for contemporaneous traders. ${ }^{49}$ This provision is seldom used; considerably more common are

45 United States v O’Hagan, 521 US 642 (1997).

4617 CFR § $240.14 \mathrm{e}-3$.

47 Salman v United States, 137 S Ct 420 (2016).

48 A C Pritchard, "The SEC at 70: Time for Retirement?", online: (2005) 80:3 Notre Dame L Rev 1086.

$<$ repository.law.umich.edu/cgi/ viewcontent.coi?article=1508\&context=articl es>; Carmen Germaine, "Rakoff Urges Securities Bar to Write Insider

Trading Law", Law 360 (1 March 2017), online:

<https:// www.law360.com/articles/ 897188/ rakoff-urges-securities-bar-towrite-insider-trading-law>.

49 Securities Exchange Act, supra note 40, § 20A. 
securities fraud class actions in which insider trading by corporate executives is alleged as a motive for misstatements.

Congress has also stepped in to correct obvious gaps in the insider trading prohibition developed by the SEC and the courts, such as trading in options. 50 Most recently, Congress was shamed into adopting a prohibition against its own members and staff trading on non-public information. ${ }^{51}$ The SEC has been similarly circumspect in its rulemaking efforts; other than Rule 14e-3, noted above, the SEC has adopted rules only when necessary to clarify issues that had created serious enforcement problems for the agency.52 One of these rules, Rule 10b5-1, also creates a defense for transactions effected through a trading plan.

The U.S. insider trading regime allows for a wide range of penalties, with monetary penalties most commonly imposed. The Exchange Act allows the SEC to sue the offender for a penalty of up to three times the profit gained or the loss avoided. ${ }^{33}$ This special penalty for insider trading is in addition to other sanctions available for fraud, including bars from serving as an officer or director of a public company, ${ }^{54}$ as an investment advisor, 55 or as an affiliate of a broker-dealer. ${ }^{56}$ Criminal prosecution is also available. ${ }^{57}$

Insider trading is an enforcement priority for the SEC, as well as for the DOJ on the criminal side. ${ }^{8}$ (Most criminal cases originate from a referral by the SEC to the DOJ .) The SEC is aided in its enforcement efforts by the surveillance efforts of the selfregulatory organizations, most importantly, the Financial Industry Regulatory Authority ("FINRA"), the New York Stock Exchange ("NYSE"), and Nasdaq. Both the SEC and the DOJ publicize their insider trading efforts, scheduling press conferences to announce the bringing of charges, as well as press releases when the government obtains settlements or wins a

50 Ibid., 20(d) (prohibiting trading in options based on material, non-public information if trading in the underlying security would be a violation).

${ }^{51}$ Stop Trading on Congressional Knowledge (STOCK) Act, Pub L No 112105, 126 Stat 291 (April 4, 2012).

52 Securities Exchange Act, supra note 40, Rule 10b5-1 (defining trading "on the basis of" material, non-public information); 10b5-2 (defining duties of trust and confidence for purposes of the misappropriation theory).

53 Securities Exchange Act, supra note 40, § 21A(a)(2).

54 Ibid., § 21(d)(2).

55 Investment Advisers Act $\S 203(\mathrm{f})$.

56 Securities Exchange Act, supra note 40, § 15(b)(6).

57 Ibid., § 32.

58 See A C Pritchard, "Insider Trading and the Ambiguous Quest for Edge" (2018) 116:6 Mich L Rev 945. 
verdict at trial. The SEC also features insider trading cases prominently when it reports annually to Congress. ${ }^{9}$ State securities regulators, by contrast, play only a peripheral role in enforcing prohibitions against insider trading. 60

\section{Comparing the Two J urisdictions}

In this section, we highlight some of the key differences between securities regulators in Canada and the U.S. The section starts with a discussion of prior comparative work on insider trading in the two jurisdictions. We then compare the public company landscape of both jurisdictions as it stands today. Next, we examine the number of insider trading matters brought by the SEC and Canadian regulators as a proportion of the regulators' overall portfolio of enforcement actions. Lastly, we discuss the resources available to the Canadian regulators and the SEC, and conclude the section by comparing penalties imposed by Canadian regulators and the U.S. SEC.

A detailed empirical analysis of insider trading cases conducted by Utpal Bhattacharya highlights two important differences between U.S. and Canadian regulators with respect to penalties. First, he found that when scaled for the respective size of the different stock markets, U.S. authorities prosecute 20 times more insider trading violations than their Canadian counterparts. ${ }^{61}$ Second, he shows that, in comparison to the OSC, the fines administered by the SEC in the U.S. are higher per insider trading case by a factor of 17.62 More specifically, Bhattacharya's analysis of the enforcement actions of the OSC for the 1997-2000 period, when scaled by the number of listed firms in the TSX and TSX Venture Exchange, shows that the total amount of fines imposed for insider trading cases was US\$700,000.63 On a per case basis, this value amounts to

59 See, e.g., SEC, Agency Financial Report, Fiscal Year 2016, at 16-17, 155.

60 One (minor) exception is the former New York Attorney General, who has made some effort to discourage trading on non-public information with the potential for market impact. See Press Release, “Att'y Gen. of N.Y. State, A.G. Schneiderman Secures Agreement By Thomson Reuters To Stop Offering Early Access To Market-Moving Information" (8 J uly 2013), online: <http:// www.ag.ny.gov/ pressrelease/ag-schneiderman-securesagreementthomson-reuters-stop-offering-early-accessmarket>.

61 Utpal Bhattacharya, "Enforcement and its Impact on Cost of Equity and Liquidity of the Market (2006), Canada Steps Up: The Report of the Task Force to Modernize Securities Legislation in Canada (Toronto, 2006), online: $<$ citeseerx.ist.psu.edu/viewdoc/ download?doi=10.1.1.522.2315\&rep=rep1\&ty pe $=p d f>$.

62 Ibid.

63 Ibid. 
US $\$ 70,300$. In comparison, for the 1997-2000 period, the fines imposed by the SEC for insider trading cases amounted to US $\$ 411,890,000.64$ On a per case basis, this value amounts to US\$1,201,000 per case.

Today, the composition of the Canadian capital market continues to differ from that of the U.S. in terms of size and number of the public companies. One important feature of the Canadian capital markets landscape is that it hosts a large number of public companies, yet its total market capitalization is not very large. ${ }^{65}$ In other words, there is a large number of very small companies. Moreover, in Canada, there is a relatively small number of very large issuers; when ranked by market capitalization, the largest 100 companies on the Toronto Stock Exchange (TSX) make up 70\% of all TSX-listed companies. ${ }^{66}$ In comparison, while there are 60 major stock exchanges throughout the world, the NYSE itself is bigger than the world's 50 smallest major exchanges and represents about $27 \%$ of the total market for global equities. ${ }^{67}$

Second, insider trading matters make up a higher proportion of the SEC's portfolio of enforcement cases when compared to those of Canadian regulators. In Canada, in 2016, illegal insider trading matters made up 8.3\% (12 of 144) of the enforcement proceedings that were commenced, and 6.5\% (17 of 262) of the enforcement files that were closed. 68 In 2015, insider trading matters made up 5.2\% (14 of 266) of the enforcement proceedings that were commenced, and $8 \%$ (28 of 350) of the enforcement files that were closed.69 In comparison, in 2016, in the U.S., cases involving trading on the basis of inside information made up 9\% (78 of 868) of the cases filed by the SEC. ${ }^{70}$ In 2015, there were 87 parties charged with insider

\footnotetext{
64 Ibid.

65 Puri, supra note 2.

66 Ibid.

${ }^{67} \mathrm{~J}$ eff Desjardins, "All of the World's Stock Exchanges by Size”, (2016)

online: <money.visualcapitalist.com/all-of-the-worlds-stock-exchanges-by-

size/ $>$.

68 See CSA, "CSA 2016 Enforcement Report” (2016) online:

$<$ www.csasanctions.ca/CSA_AnnualReport2016_English_Final.pdf>.

69 Ibid.

70 See SEC Press Release, "SECAnnounces Enforcement Results for FY

2016" (11 October 2016) online:

<https:// www.sec.gov/ news/pressrelease/ 2016-212.html>.
} 
trading, making insider trading $10.8 \%$ of SEC's overall portfolio of 807 enforcement actions for the year. ${ }^{71}$

Although Canada's provincial structure of market oversight makes it challenging to estimate the total budget for securities market oversight, previous studies highlight the differences between the Canadian and the U.S. regulatory systems in terms of their budgets and staffing levels. Several studies show that, when adjusted for deflators such as market size, population and GDP, the levels of Canadian securities regulatory staffing and budget are actually slightly more intensive in comparison to the U.S.72 For example, the 2014 annual report by the Financial Services Authority of the United Kingdom (FSA Report) suggests that, once normalized for equity market size, the supervisory budget of the Canadian securities regulation is more intensive than that of the U.S. ${ }^{73}$ More specifically, while the FSA Report estimates Canadian securities regulation budget per billion dollars of market cap at US $\$ 220,515$, the U.S. budget was estimated at US $\$ 83,943 .{ }^{74}$ In a more recent study, Howell J ackson attempts to normalize the data by considering other factors, such as population and GDP. He finds that although the U.S. regulators, which include state regulators in addition to the SEC, have a regulatory budget and staffing that is 5 to 9 times larger than Canada, the U.S. market is also 10 times larger. ${ }^{75}$ In other words, although the U.S. securities regulators are spending more per staff member than their Canadian counterparts, ${ }^{76}$ they also have a market that is larger by a greater factor. As J ackson suggests, this implies that when normalized for population, GDP, or market capitalization, Canadian regulatory budgets and staffing are more intense than that of the U.S. ${ }^{77}$

In addition, Canadian and U.S. regulatory budgets also differ with respect to the proportion of resources allocated to enforcement activities, with Canadian regulators spending a

${ }^{71}$ See SEC Press Release, "SEC Announces Enforcement Results for FY 2015" (22 October 2015) online: <https:// www.sec.gov/ news/ pressrelease/ 2015245.html>.

72 See Howell EJ ackson, "Regulatory Intensity in the Regulation of Capital Markets: A Preliminary Comparison of Canadian and U.S. Approaches" (2006), Canada Steps Up: The Report of the Task Force to Modernize Securities Legislation in Canada (Toronto, 2006), at 81.

${ }^{73}$ Ibid.

74 Ibid.

75 Ibid, at 97.

76 Ibid, at 94.

77 Ibid, at 97. 
lower proportion of their regulatory budget on enforcement than the SEC. In 2016, the SEC had a total budget of US $\$ 1.9$ billion, of which US $\$ 1.7$ billion was allocated to facilitating its programs. 78 Of the $\$ 1.7$ billion of this budget, 35\% (US\$595 million) was allocated to programs led by the Enforcement Division. ${ }^{79}$ In comparison, Canadian regulators allocate a lower proportion of their budget to enforcement activities. Although the portion of the regulatory budget allocated to enforcement is not generally disclosed by provincial regulators, previous studies show that, in general, securities commissions spend between $10 \%$ to $20 \%$ of their total budgets on enforcement. 80 A study conducted by Charles River Associates shows that, in 2002, the OSC allocated over CAD $\$ 9$ million of its budget to enforcement activities, while Quebec, B.C., and Alberta spent \$4.4, \$3.5, and \$3.1 million respectively. ${ }^{81}$

In conclusion, Canada and the U.S. differ in terms of their capital market and regulatory landscape. First, insider trading matters make up a higher proportion of the SEC's portfolio of enforcement cases when compared to those of Canadian regulators. Second, in comparison to the U.S. regulators, Canadian securities regulators have slightly more intensive staffing and budgets, but they allocate a smaller portion of their budget to enforcement activities. However, it is important not to draw the premature conclusion that these differences are a result of a different propensity for enforcing capital market rules in the two jurisdictions. ${ }^{82}$ As suggested by Puri, structural inefficiencies or unique regulatory priorities (i.e., prioritizing compliance over enforcement) and challenges could be the factors that result in differences in enforcement activity. ${ }^{83}$ In the next section, we introduce our eight hypotheses that focus on the differences in insider trading enforcement actions in Canada and the U.S.

\footnotetext{
78 See table in the SEC, "US SEC Summary of Performance and Financial Information FY2016 report" (2017) online:

$<$ https:// www.sec.gov/ files/ 2017-03/ sec-summary-of-performance-andfinancial-info-fy2016.pdf>, at 15.

79 Ibid at 15-16.

80 See Poonam Puri, "Enforcement Effectiveness in the Canadian Capital Markets" (2005) Commissioned Reports and Studies. Paper 3, online: $<\mathrm{http}$ :// digitalcommons.osgoode.yorku.ca/ cgi/ viewcontent.cgi?article=1002 \&context=reports>. See also Charles River Associates, "Securities

Enforcement in Canada: The Effect of Multiple Regulators, study prepared for the Wise Persons' Committee" (December 2003).

81 Ibid.

82 Puri, supra note 2.

83 Ibid.
} 


\section{Hypotheses}

One may assume that the SEC has greater resources, more economies of scale, and more expertise in bringing insider trading actions. ${ }^{84}$ More importantly, the greater trading volume of the U.S. capital markets suggests that the total incidence of insider trading will be significantly greater in the U.S. (greater trading volume makes it easier to conceal informed trades from other traders; it is difficult to conceal informed trading in small cap companies). These factors suggest that the SEC will bring more insider trading actions than its Canadian counterparts. It is possible that Canadian regulators will be able to bring relatively more insider trading actions to the extent the Canadian actions involve more straightforward fact patterns. This effect is unlikely to outweigh, however, the greater size of the U.S. capital markets.

\section{Hypothesis 1: The U.S. will have more insider trading actions than Canada, both in absolute numbers and as scaled by the market capitalization of publicly traded firms in both markets.}

The more cosmopolitan nature of the U.S. capital markets leads us to our next hypothesis. The number of cross-listed firms is substantially greater on U.S. exchanges than on Canadian

84 For reference, in 2015 the U.S. Securities and Exchange Commission spent \$1.586 billion on enforcement activities while Ontario, British Columbia, Alberta, New Brunswick and Manitoba spent \$98.870 million, \$47.7 million, \$38.495 million, \$9.9 million, and \$5.036 million, respectively, on enforcement activities. For a full examination of budget and personnel differences see: SEC, "FY 2017 Congressional Budget J ustification; FY 2017 Annual Performance Plan; FY 2015 Annual Performance Report" (9 February 2016), online: <https:// www.sec.gov/ reportspubs/ budgetreports/ about-reports-secfy17congbudgjustshtml.html>; Ontario Securities Commission, Annual Report 2015, (8 J une 2015), online:

$<w w w . o s c . g o v . o n . c a / d o c u m e n t s /$ en/Publications/Publications_rpt_2015_o sc-annual-rpt_en.pdf>; British Columbia Securities Commission,

2015/ 2016-2017/2018 (2016), online:

<www.bcbudget.gov.bc.ca/ 2016/sp/pdf/ agency/ bcsc.pdf>; Alberta

Securities Commission, 2015 Annual Report (2015), online:

$<$ www.albertasecurities.com/ Publications/2015_ASC-

Annual_Report_Web.pdf>; Financial and Consumer Services Commission, "2015-2016 Annual Report" (2016) online:

<http:// 0104.nocdn.net/ 1_5/ 1c7/ 37a/ 1bc/ Annual-Report-2015-2016.pdf>;

Manitoba Securities Commission, "Pride, Protection, Purpose: Manitoba

Financial Services Agency 2016 Annual Report" (2016), online:

<http://www.mbsecurities.ca/about-msc/pubs/2016_ar.pdf>. 
exchanges. ${ }^{85}$ Although insider trading enforcement may be primarily intended to promote market integrity, it arguably promotes corporate governance improvements as well. Those benefits might accrue primarily in the jurisdiction where the foreign company is headquartered. The SEC is more likely to score points with Congress for "renting" the U.S.'s reputation for quality corporate governance to foreign companies than Canada's provinicial regulators are with their respective legislatures. Consequently, Canadian securities regulators are more likely to focus on insider trading actions involving insiders of Canadian companies that are not cross-listed. In addition, the SEC's greater resources give it a greater ability to pursue insider trading actions involving foreign companies, which pose a greater challenge for regulators when collecting evidence.

\section{Hypothesis 2: The U.S. will bring more insider trading actions involving foreign public companies as a fraction of all insider trading actions.}

Our next hypothesis relates to case complexity. We postulate that Canadian regulators will tend to avoid actions involving multiple companies. Actions involving insider trading conspiracies, in which information about different companies is shared among the conspirators, frequently involve investment professionals trading in multiple firms. (Financial institutions afford more trading opportunities, but they also face stringent compliance regimes, which may require cooperation with others in an effort to avoid detection.) These cases are likely to be more complicated, and consequently, will take greater resources to establish the connections among the co-conspirators.

An implicit assumption of this hypothesis is that the number of underlying insider trading violations involving multiple companies for Canada and the U.S. is similar once scaled by the size of the economy. Any differences in the

${ }^{85}$ Currently, there are about 491 non-U.S. issuers on the NYSE and 108 nonU.S. issuers on the NASDAQ. In comparison, there are 236 non-Canadian companies on the TSX and TSXV. Of those international companies, 121 (51\%) are American companies. For more see Toronto Stock Exchange, “Guide to Listing” (2017), online: <https:/ / www.tsx.com/ resource/ en/ 181>; New York Stock Exchange, "International Listings: Documents and Reports" (30 J une 2017) online: <https:/ / www.nyse.com/get-

started/international/ documents-reports> [NYSE]; NASDAQ, "NASDAQ -

Non-U.S. Companies" (2017), online:

$<$ http:// www.nasdaq.com/ screening/ companies-byindustry.aspx? exchange $=\mathrm{NASDAQ} \&$ market $=\mathrm{ADR}>$. 
incidence of multiple company enforcement are therefore due to differences in how regulators in each country deal with multiple company insider trading violations. Although we cannot test this assumption explicitly, we do note that most conspiracies involving insider trading at multiple companies involve individuals associated with financial institutions. As a percentage of the total economy, Canada's financial sector is comparable to that of the U.S., 86 consistent with the assumption of a roughly equivalent number of underlying insider trading violations involving multiple companies scaled by economy size.

\section{Hypothesis 3: U.S. actions will involve more actions involving multiple traded companies as a fraction of all insider trading actions.}

Continuing with the theme of case complexity, we predict that the number of defendants for each action will be greater in the U.S. than in Canada. Greater resources allow the SEC to prosecute more complicated networks and more readily track down all of the potential co-conspirators. In addition, targeting tippers or tippees will require unraveling more complicated fact patterns, as will pursuing top insiders at a public company, who may also have greater resources to defend against an enforcement action. As discussed above, Canada and the U.S. differ in their respective legal regimes governing tipper-tippees. On the one hand, the U.S. regime is primarily common lawbased, requiring a breach of fiduciary duty, leading to greater uncertainty of interpretation for regulators bringing tippertippee actions. On the other hand, the legal requirements in Canada, where a "special relationship" and the transmission of a material fact or material change must be demonstrated for tipper-tippee liability, are challenging to prove and may require more expenditure to prosecute. As a result, differences in tipper or tippee enforcement actions between Canada and the U.S. could also be due to the varying costs of enforcement in the two countries.

\section{Hypothesis 4: U.S. actions will have more defendants.}

Hypothesis 5: U.S. actions will be more likely to include tippers or tippees and top insider defendants.

${ }^{86} \mathrm{~J}$ eff Desjardins, "A Tale of Two Banking Sectors: Canada vs U.S." (16 May 2018), online (blog): Visual Capitalist, <http:// www.visualcapitalist.com/ canada-u-s-banking-differences/>. 
The SEC is familiar with criminal process, frequently cooperating with the DOJ in bringing securities fraud cases. In addition, the U.S. DOJ has a long-established track record prosecuting financial market crimes. In contrast, Canada has less experience pursuing insider trading in criminal proceedings. This inexperience may, in part, reflect the constitutional division of powers between the federal government and the provinces. In addition, Canadian investigation and prosecution of criminal actions is diffused among federal and provincial bodies, making parallel criminal actions more complicated. ${ }^{87}$ Thus, the outcome of criminal prosecution is likely to be more uncertain, while also requiring a high level of enforcement resources. Accordingly, we predict, given equally egregious facts, the SEC will be more likely to make a referral resulting in criminal enforcement than Canadian regulators.

\section{Hypothesis 6: U.S. actions will be more likely to generate a criminal referral.}

Our next hypothesis relates to predictability. Predictability may lead to a greater probability of settlement because both the government and the defendant will be better able to forecast the likely outcome from adjudication. On the one hand, the U.S.'s greater experience with insider trading actions and larger stock of precedents makes enforcement more predictable. On the other hand, Canadian law more clearly sets forth the elements of the offense in statutes, avoiding some of the uncertainty generated by the U.S.'s largely common law approach to insider trading.

Predictability is not the entire story, however, when it comes to settlement rates. Resources also matter: the greater the resources available for the government, the less likely defendants will be to take their chances with adjudication. The SEC has more enforcement actions to manage than its Canadian counterparts, but its greater capacity allows it to bring more resources to bear

${ }^{87}$ For more on the difficulties in pursuing criminal prosecutions for capital markets offenses in Canada, see Poonam Puri, "Enforcement Effectiveness in the Canadian Capital Markets" (2005) Commissioned Reports and Studies.

Paper 3. online:

$<$ http:// digitalcommons.osgoode.yorku.ca/ cgi/ viewcontent.cgi?article=1002 \&context=reports>; and Poonam Puri, "A Model for Common Enforcement in Canada: The Canadian Capital Markets Enforcement Agency and the Canadian Securities Hearing Tribunal" (2008) Commissioned Reports and Studies. Paper 111, online: $<\mathrm{http}$ // digitalcommons.osgoode.yorku.ca/ cgi/ viewcontent.cgi?article=1110 \&context=reports $>$. 
if defendants choose to resist. Given the uncertainty over which regime provides greater predictability, we postulate that the "resource effect" dominates and that the settlement rate will be greater in the U.S.

\section{Hypothesis 7: U.S. enforcement actions will be more likely to produce a settlement.}

Like hypothesis 7, our final hypothesis also relates to outcomes: what sanctions are imposed as a result of the insider trading enforcement action? Both countries make available a range of sanctions for those punished for insider trading, including disgorgement of unlawful gains (or losses avoided), prejudgment interest on those gains, monetary penalties, and bars. Bars may preclude an individual from serving as an officer or director of a public company, or may limit the ability of an individual to serve in the financial industry as a registered representative of a broker-dealer or investment adviser.

We postulate that, consistent with Canada's pursuit of more straightforward insider trading actions, insider trading actions will result in lower monetary sanctions because trading profits may not be as great if enforcement does not target complicated conspiracies. We posit that trading profits are higher for more complicated insider trading actions involving multiple companies and defendants. Because of the lower monetary sanctions available, Canada will rely more on bars to adjust behavior. In the event that a bar is imposed in both countries, however, the U.S. is more likely to make the bar permanent. This reflects the SEC's greater resources, which it may be willing to commit to exclude the most egregious offenders from positions that would allow them to repeat their illegal behavior. By contrast, Canadian regulators may be more likely to use their administrative power as a first line of enforcement; if those bars prove ineffective, subsequent actions and the sanctions levied may be more draconian.

Hypothesis 8A: The U.S. will impose greater penalties, especially disgorgement and monetary penalties.

Hypothesis 8B: Canada will be more likely to impose temporary bars, while the U.S. will be more likely to impose a permanent bar.

\section{Empirical Results}




\section{A. Sample}

To collect our sample, we identified all insider trading enforcement actions brought by the securities commissions in Alberta, British Columbia, Nova Scotia, Ontario, and Québec from 2005 to 2015. (Our research did not uncover any insider trading cases brought by the regulatory authorities in the other Canadian provincial and territorial jurisdictions.) Using enforcement releases issued by the SEC, we also collected insider trading actions brought by that agency for the same period. For each of the actions, we identified the defendant(s) and their relationship to the traded company(ies). Wealso coded a number of features of the actions, including the filing and resolution dates, the outcomes of the cases and any sanctions imposed, and whether there were criminal referrals leading to prosecution. (We did not treat the criminal cases as separate observations.) Table 1 below shows the number of actions brought in each country broken down by the year initiated.

Table 1: Insider Trading Enforcement Actions in Canada and the U.S.

\begin{tabular}{|l|c|c|c|c|}
\hline Year & CA & US & \multicolumn{2}{|c|}{$\begin{array}{c}\text { CA-US Percent of } \\
\text { Combined Actions }\end{array}$} \\
\hline 2005 & 4 & 39 & $9.3 \%$ & $90.7 \%$ \\
\hline 2006 & 7 & 41 & $14.6 \%$ & $85.4 \%$ \\
\hline 2007 & 4 & 38 & $9.5 \%$ & $90.5 \%$ \\
\hline 2008 & 6 & 38 & $13.6 \%$ & $86.4 \%$ \\
\hline 2009 & 13 & 38 & $25.5 \%$ & $74.5 \%$ \\
\hline 2010 & 11 & 35 & $23.9 \%$ & $76.1 \%$ \\
\hline 2011 & 10 & 46 & $17.9 \%$ & $82.1 \%$ \\
\hline 2012 & 3 & 55 & $5.2 \%$ & $94.8 \%$ \\
\hline 2013 & 6 & 41 & $12.8 \%$ & $87.2 \%$ \\
\hline 2014 & 2 & 51 & $3.8 \%$ & $96.2 \%$ \\
\hline 2015 & 7 & 32 & $17.9 \%$ & $82.1 \%$ \\
\hline Total & 73 & 454 & $13.9 \%$ & $86.1 \%$ \\
\hline
\end{tabular}

Unsurprisingly, the number of actions is much larger in the U.S., reflecting its larger economy and deeper capital markets. The overall ratio of U.S. actions to Canadian actions is 6.2 to 1 , consistent with Hypothesis $1 .{ }^{88}$ If we look at that number

88 Although the number of actions is lower in Canada than the United States, it is possible that the number of defendants per action may be higher in Canada. To address this possibility, we computed the aggregate number of 
relative to the amount of trading, however, the intensity of enforcement in Canada looks considerably greater. According to the World Bank, the value of shares traded in Canada was \$1,096 billion U.S. in 2015, while in the U.S., the corresponding number was $\$ 41,398$ billion U.S. for the same year. 89 The ratio of trading in the U.S. relative to Canada is 37.8 to 1 . Adjusting for trading volume, Canada would appear to have a considerably greater intensity of enforcement when compared to the U.S., inconsistent with Hypothesis $1 .^{90}$

Of note, consistent with the research of Anand and Green, we found that the number of Canadian actions spiked in the wake of the financial crisis of 2007 and 2008, whereas the U.S. numbers stayed relatively steady. ${ }^{11}$ Of course, these ratios offer only a crude comparison because they omit the actual incidence of insider trading, a data point that is unavailable given the clandestine nature of the conduct. These raw numbers also do not control for the type of insider trading; it is possible that U.S. enforcement actions tackle more complicated insider trading conspiracies, which would require greater enforcement resources. Consistent with this conjecture, the number of enforcement actions in the U.S. appears to be greater in the second half of our sample period, when the Federal Bureau of Investigation began using wire taps to target insider trading among hedge funds.

defendants for all actions in Canada (127) and the United States (2,138). The ratio of the number of U.S. defendants to Canadian defendants is 16.8 to 1 , consistent with Hypothesis 1.

89 World Bank, "Indicators" (2018), online:

$<$ http:// data. worldbank.org/indicator/ CM.MKT.TRAD.CD>.

90 We also compared the number of listed domestic companies (including foreign companies which are exclusively listed) as tracked by the World Bank for Canada and the United States in 2015. See World Bank, "Indicators" (2018), online:

$<$ http:// data.worldbank.org/indicator/ CM.MKT.LDOM.NO>. The ratio of listed domestic companies in the United States (4,381 listed companies) to Canada (3,799 listed companies) is only 1.1. The large number of listed listed companies in Canada relative to the size of its economy reflects a high percentage of small market capitalization firms with relatively low trading volume. To the extent trading volume better approximates the opportunities for an insider to take advantage of their inside information, we think that the comparison of trading volume between the U.S. and Canada is a better metric for the relative sizes of the capital markets of the two countries than the number of listed companies.

${ }^{91}$ Anita Anand \&Andrew Green, "Securities Settlements as an Example of Crisis-driven Regulation" (2018) 55 Int Rev L \& Econ 41. 
We also applied the Standard Industry Classification (SIC) one-digit industry code to the traded companies in the actions and grouped them into seven categories, as reported in Table 2. For the actions with multiple traded companies, we coded each traded company separately. Table 2 compares the frequency of insider trading actions in the seven industry groupings for the two countries.

Table 2: SIC One-Digit Industry Classification for Traded Companies

\begin{tabular}{|l|c|c|c|c|}
\hline \multicolumn{1}{|c|}{ Industry Classification } & CA & $\begin{array}{c}\text { Percent } \\
\text { of Total } \\
\text { for CA }\end{array}$ & US & $\begin{array}{c}\text { Percent } \\
\text { of Total } \\
\text { for US }\end{array}$ \\
\hline $\begin{array}{l}\text { Agriculture, Forestry and } \\
\text { Fishing (SIC 0) }\end{array}$ & 1 & $1.4 \%$ & 1 & $0.1 \%$ \\
\hline Mining \& Construction (SIC 1) & 40 & $55.6 \%$ & 22 & $2.7 \%$ \\
\hline Manufacturing (SIC2 and 3) & 11 & $15.3 \%$ & 401 & $48.7 \%$ \\
\hline $\begin{array}{l}\text { Transportation, } \\
\text { Communications, Electric, Gas } \\
\text { and Sanitary service (SIC4) }\end{array}$ & 2 & $2.8 \%$ & 41 & $5.0 \%$ \\
\hline $\begin{array}{l}\text { Wholesale \& Retail Trade (SIC } \\
\text { 5) }\end{array}$ & 3 & $4.2 \%$ & 93 & $11.3 \%$ \\
\hline $\begin{array}{l}\text { Finance, Insurance and Real } \\
\text { Estate (SIC 6) }\end{array}$ & 12 & $16.7 \%$ & 99 & $12.0 \%$ \\
\hline Services (SIC 7 and 8) & 3 & $4.2 \%$ & 167 & $20.3 \%$ \\
\hline Total & 72 & $100.0 \%$ & 824 & $100.0 \%$ \\
\hline
\end{tabular}

Chi2(2) = 302.7; Prob. $=0.000$.

The striking number from the table is the large proportion of firms in the mining and construction industries on the Canadian side. This is unsurprising given that mining issuers dominate the Canadian stock exchanges, representing almost one half of the total issuers on the TSX Venture Exchange. ${ }^{92}$ The natural resources sector is also very important to the overall Canadian economy, and it may be that the nature of this cyclical business, with its potential for dramatic variances in underlying commodity prices and boom/bust results, creates an added incentive for insider trading. Additionally, regulatory discretion

92 Poonam Puri, "The Role of Local and Regional Interests in the Design of Optimal Securities Regulatory Structure for Canada” (2003), online:

$<$ http:/ / digitalcommons.osgoode.yorku.ca/ reports/ 118/ >. See also TMX, "S\&P/TSX Venture Composite Index" (2018), online: <

https:// web.tmxmoney.com/index_sector.php?qm_symbol=\%5EJ X>. 
may lead to a greater emphasis on insider trading cases in the natural resources sector. 93

\section{B. Empirical Tests}

Hypothesis 2 postulates that the U.S. may be more inclined to use its enforcement resources to investigate trading in companies incorporated outside the U.S. For actions with a single traded company, we determined the country of incorporation for the traded company. For the actions with multiple traded companies, we coded the country of incorporation for each traded company separately. We report the country of incorporation for the Canadian and U.S. insider trading actions in our dataset in Table 3.

Table 3: Country of Incorporation

\begin{tabular}{|l|c|c|c|c|}
\hline $\begin{array}{l}\text { Country of } \\
\text { Incorporation }\end{array}$ & $\begin{array}{c}\text { Canadian } \\
\text { Actions }\end{array}$ & $\begin{array}{c}\text { Percent } \\
\text { of all CA } \\
\text { Actions }\end{array}$ & $\begin{array}{c}\text { US } \\
\text { Actions }\end{array}$ & $\begin{array}{c}\text { Percent } \\
\text { of all US } \\
\text { Actions }\end{array}$ \\
\hline Canada & 57 & $93.4 \%$ & 26 & $3.2 \%$ \\
\hline US & 3 & $4.9 \%$ & 737 & $91.8 \%$ \\
\hline Other & 1 & $1.6 \%$ & 40 & $5.0 \%$ \\
\hline Total & 61 & $100.0 \%$ & 803 & $100.0 \%$ \\
\hline
\end{tabular}

Chi2(2) =531.5; Prob. $=0.000$.

As reported in Table 3, Canadian securities regulators primarily concern themselves with insider trading in Canadian companies, while the SEC brings more insider trading enforcement actions against companies incorporated outside the

93 The largest number of firms in Table 2 is in the Manufacturing (SIC 2 and 3) category. In the following table we report the breakdown for those threedigit SIC categories within the Manufacturing category where there are more than ten firms from either the United States and Canada in the three-digit category.

\begin{tabular}{|l|c|c|}
\hline SIC & CA & US \\
\hline 283 (Drugs) & 2 & 127 \\
\hline 357 (Computer and Office Equipment) & 2 & 39 \\
\hline 366 (Communications Equipment) & 0 & 30 \\
\hline 367 (Electronic Components and Accessories) & 1 & 54 \\
\hline $\begin{array}{l}384 \text { (Surgical, Medical, and Dental } \\
\text { Instruments and Supplies) }\end{array}$ & 0 & 36 \\
\hline
\end{tabular}


U.S. (and outside of Canada). This broader focus presumably reflects the greater incidence of cross-listing in the U.S., ${ }^{94}$ making it likely that the trading was done on a U.S. exchange, even if the company's headquarters and operations are located elsewhere.

We next examine the complexity of the cases investigated. Hypothesis 3 posits that the SEC, with its greater resources, will be more inclined to take on complicated insider trading rings. This may manifest itself in investigations involving multiple traded companies, as insider trading conspirators exchange information in various companies. Table 4 compares the likelihood that an insider trading enforcement action involves multiple companies.

Table 4: Multiple Company Actions

\begin{tabular}{|l|c|c|c|}
\hline & CA & US & t-test \\
\hline Multiple Companies & $21.9 \%$ & $20.5 \%$ & 0.257 \\
\hline & & & \\
\hline
\end{tabular}$\quad<0.10,{ }^{*} \mathrm{p}<0.05,{ }^{* *} \mathrm{p}<0.01$.

Inconsistent with Hypothesis 3, we do not find significant differences in the fraction of actions involving multiple traded companies between Canada and the U.S. Investigations involving multiple companies constitute $20.5 \%$ of the actions in the U.S. and $21.9 \%$ of the actions in Canada.

94 NYSE, supra note 85. The NYSE, America's largest stock exchange by market capitalization, had 451 non-U.S. issuers in 2006, 422 in 2007, 412 in 2008, 496 in 2009, 519 in 2010, 521 in 2011, 525 in 2012, 520 in 2013, 528 in 2014, 515 in 2015, and 487 in 2016. Currently there are 491 non-U.S. issuers on the NYSE. In contrast, the TMX group (which operates the TSX and TSXV, by far the largest stock exchanges in Canada) has fluctuated between 205 non-Canadian issuers in 2006 to 236 international issuers today. For more see, TSX Group, Annual Reports 2006 through 2017. When combining the NYSE with other major American stock exchanges, such as the Nasdaq and AMEX, the gap between rates of cross-listing between the two jurisdictions grow even larger. Specifically, there are approximately 724 foreign issuers on the three largest American stock exchanges. See Nasdaq, "Companies by Industry," (1 August 2017), online: $<$ www.nasdaq.com/ screening/ regions.aspx>. Across the entire U.S. there have been between 912 to 1145 foreign companies registered and reporting with the U.S. Securities and Exchange Commission between 2006 and 2014 (this number includes companies traded on the Over the Counter Market). See SEC, "International Registered and Reporting Companies", online: (2014)

<https:// www.sec.gov/ divisions/ corpfin/ internatl/ companies.shtml>. 
Another aspect of complexity is the number of defendants involved in a particular investigation or case. This issue implicates not only the number of people who may have been trading on the information, but also potentially the sources of the information. The latter topic is not simply a matter of factual complexity, which may demand more investigative resources, but it is also a matter of the elements required under the tipping regime of the respective jurisdictions. The U.S. regime is quite complicated as a doctrinal matter, with the elements of tipping somewhat murky. The more clearly delineated statutes in Canada, however, pose a challenge for regulators because they are required to show that the tipper was in a "special relationship" with the issuer and that he or she passed on a material fact or material change.

Panel A of Table 5 compares the mean number of defendants in insider trading actions. Panel B of Table 5 presents the results of a negative binomial regression, with the number of defendants in an action as the dependent variable. We include an indicator variable for U.S. actions as our variable of interest in this regression. We also include a control variable for the number of companies involved in the action, as a larger number of companies may correlate with a larger number of defendants. Thus, the U.S. variable captures the increment beyond that provided by the U.S. having a larger average number of companies in its actions.

\section{Table 5: Defendants}

\section{Panel A: Average Number of Defendants}

\begin{tabular}{|c|c|c|c|}
\hline & CA & US & t-test \\
\hline Defendants & 1.45 & 2.31 & $-3.147^{* *}$ \\
& \multicolumn{3}{|c|}{} \\
+
\end{tabular}

Panel B: Negative Binomial Regression Analysis of the Number of Defendants

\begin{tabular}{|l|l|}
\hline Variable & Coefficient \\
\hline US & $\begin{array}{l}0.424^{* *} \\
(0.122)\end{array}$ \\
\hline Multiple Company & $\begin{array}{l}0.519^{* *} \\
(0.080)\end{array}$ \\
\hline Constant & $0.284^{*}$ \\
\hline
\end{tabular}




\begin{tabular}{|l|l|}
\hline & $(0.118)$ \\
\hline $\mathrm{N}$ & 518 \\
\hline Pseudo $^{2}$ & 0.027 \\
\hline
\end{tabular}

Dependent variable of negative binomial regression is the number of defendants in an action. Standard errors in parentheses. ${ }^{+} p<0.10$, * $\mathrm{p}<0.05,^{* *} \mathrm{p}<0.01$.

Consistent with Hypothesis 4, we see that U.S. investigations involve a significantly greater number of defendants. This finding is consistent with greater resources on the part of U.S. regulators. Pursuing chains of tipper-tippees may require greater resources to investigate, favoring U.S. regulators. Legal differences governing tipper-tippee liability between the two countries may also be determinative.

To explore this possibility further, we code the type of defendants in the insider trading actions. We examine whether a tipper or tippee is included in the action. We also examine whether a top insider was named as a defendant. A top insider is defined as either a current or former member of the board of directors or executive officer (including the CEO, CFO, President, $\mathrm{COO}$, General Counsel, Senior Vice President, Vice President, or Treasurer). Table 6 compares incidence of these two types of defendants for insider trading actions between the two countries.

\section{Table 6: Type of Defendant in Action}

\begin{tabular}{|l|c|c|c|}
\hline & CA & US & t-test \\
\hline Tipper/Tippee & $27.0 \%$ & $57.4 \%$ & $-4.609^{* *}$ \\
& & & \\
\hline Top Insider & $31.7 \%$ & $32.7 \%$ & -0.144 \\
\hline
\end{tabular}
$+\mathrm{p}<0.10,{ }^{*} \mathrm{p}<0.05,{ }^{* *} \mathrm{p}<0.01$.

Consistent with Hypothesis 5, the SEC is more than twice as likely to pursue tippers or tippees, a difference significant at the $1 \%$ level.95 By contrast, we see no significant difference in the likelihood that a top insider will be pursued, inconsistent with Hypothesis 5. We cannot say whether the lower percentage of

${ }^{95}$ It is possible that the tipper/ tippee numbers for the U.S. were inflated from 2010 onward due to increased insider trading enforcement against hedge funds during this time period. To address this possibility, we compared the incidence of tipper/ tippee defendants in actions from 2005 to 2009 only. We found that the incidence of tipper/ tippees in Canada (20.0\%) remains below the incidence of tipper/ tippees in U.S. actions (52.6\%) for the 2005 to 2009 time period and this difference is significant at the $1 \%$ confidence level. 
tipping cases in Canada reflects greater compliance efforts or a different standard of proof or enforcement focus. We note, however, that in criminal and quasi-criminal matters, no successful tipping case in Canada has been upheld on appeal. ${ }^{96}$

For the remainder of our tests, we focus on the specific defendants associated with insider trading actions. We examine the likelihood of a criminal case being pursued as part of the insider trading action for a particular defendant. To examine this question, we estimate a logistic regression with the dependent variable coded as 1 if there is a criminal action for a defendant based on the same set of facts as the civil insider trading action. The regression is estimated on defendant-action level data. Our independent variable of interest is the U.S., but we also include control variables: the log of 1 plus the amount of profits gained from the trading; indicator variables coded as 1 if a tipper or tippee or top insider were named as defendants, which may reflect culpability and/ or enforcement priorities. Wealso include an indicator variable, Fin Inst, if any defendant included in the conspiracy is employed by a financial institution, such as a bank or broker-dealer, which may face a higher level of scrutiny. (We also include employees of accounting firms in this category, given the regulatory scrutiny faced by that profession.) We present the results in Table 7.

96 One of the most high-profile tipping cases in the recent past was the case of R v Rankin, 2005 CarswellOnt 4068 (OCJ ); R v Rankin (2006), 42 CR (6 $6^{\text {th) }} 297$ (ONSC); R v Rankin (2007), 216 CCC (3d) 481, 221 OAC 184 (Ont. CA) [Rankin]. In this case, Andrew Rankin, a managing director in the mergers and acquisitions department of RBC Dominions Securities, was charged with 20 counts of insider trading and tipping under ss.76(1) and (2) of the OSA. The evidence in the case was the testimony of the alleged tippee and circumstantial evidence that documented the timing of the tippee's trades and his connection to Rankin. He was acquitted of the ten counts of insider trading, but convicted on the tipping charges and sentenced to six months in prison concurrent on each count. This case was significant because it was the first Canadian case to yield a conviction of tipping. However, when the case was overturned and leave to appeal denied, the case came to stand as another example of how difficult enforcing insider trading and tipping is. 
Table 7: Logistic Regression Analysis of Criminal Cases

\begin{tabular}{|l|l|}
\hline Variable & Coefficient \\
\hline US & $\begin{array}{l}2.197^{* *} \\
(2.76)\end{array}$ \\
\hline $\ln$ (Profits) & $\begin{array}{l}-0.001 \\
(-0.03)\end{array}$ \\
\hline Tipper/Tippee & $\begin{array}{l}0.883^{* *} \\
(3.58)\end{array}$ \\
\hline Top Insider & $\begin{array}{l}0.751^{*} \\
(2.45)\end{array}$ \\
\hline Fin Inst & $\begin{array}{l}1.049^{* *} \\
(3.94)\end{array}$ \\
\hline Constant & $-4.607^{* *}$ \\
& $(-5.39)$ \\
\hline $\mathrm{N}$ & 1057 \\
\hline Pseudo ${ }^{2}$ & 0.081 \\
\hline
\end{tabular}

Dependent variable is coded as 1 if there is criminal prosecution involving a defendant. Standard errors in parentheses. z-statistics in parenthesis. Errors are clustered by action. ${ }^{+} \mathrm{p}<0.10,{ }^{*} \mathrm{p}<0.05,{ }^{* *} \mathrm{p}$ $<0.01$.

We found that U.S. cases are significantly more likely to result in a criminal referral leading to prosecution, consistent with Hypothesis 6.97 The lower likelihood of criminal prosecution in Canada may reflect a lack of experience and precedential success in Canada with such cases (U.S. cases date to the 1970s), more demanding elements or burden of proof, a lower budget for enforcement, the diffuse regulatory structure, or a different cultural understanding of the types of behavior that should be proscribed by a criminal sanction. 98

97 We cannot know if there was a criminal referral that the prosecutor declined; we only see prosecutions actually brought.

98 The Hon. Peter de C Cory \& Marilyn L Pilkington, "Critical Issues in Enforcement" (2008), Canada Steps Up: The Report of the Task Force to Modernize Securities Legislation in Canada (Toronto, 2006), at 171-172, 191-197; Laura Nyantung Beny and Anita Anand, "Private Regulation of Insider Trading in the Shadow of Lax Public Enforcement: Evidence from Canadian Firms", online: (2013) 3:2 Harv Bus L Rev 227-229

$<$ repository.law.umich.edu/cgi/viewcontent.coi?article=1641\&context=articl es $>$ [Cory and Pilkington]. See generally, for the differences in enforcement policies and priorities among the Canadian provincial commissions leading to suboptimal enforcement as compared to a common regulator, and for a comparison of enforcement activity and effectiveness in Canada and the U.S., Poonam Puri, "Enforcement Effectiveness in the Canadian Capital Markets", Commissioned Reports and Studies. Paper 3 (2005), at 21-22, 2426. 
Our final set of comparisons looks at the outcomes of enforcement actions for defendants in an action. First, we look at the likelihood of settlement. All else equal, a more respected/feared regulator should be better able to induce defendants to settle an enforcement action. Conversely, defendants may be more willing to take their chances in adjudication if the enforcement agency is untested or has limited resources. We assess this question using a logit model with the dependent variable coded as 1 if a defendant settled an action and 0 if a defendant contested an action. The regression is estimated on defendant-action-level data. We include the U.S. as our independent variable of interest, along with the control variables used in the regression presented in Table 7 . We present the results in Table 8.

Table 8: Logistic Regression Analysis of Settlement

\begin{tabular}{|l|l|}
\hline Variable & Coefficient \\
\hline US & $1.610^{* *}$ \\
& $(4.02)$ \\
\hline $\ln$ (Profits) & 0.028 \\
& $(0.79)$ \\
\hline Tipper/Tippee & 0.356 \\
& $(1.08)$ \\
\hline Top Insider & 0.035 \\
& $(0.10)$ \\
\hline Fin Inst & -0.407 \\
& $(-1.18)$ \\
\hline Constant & 0.418 \\
& $(0.91)$ \\
\hline $\mathrm{N}$ & 1,035 \\
\hline Pseudo $\mathrm{r}^{2}$ & 0.057 \\
\hline
\end{tabular}

Dependent variable is coded as 1 if case is settled for a defendant and 0 otherwise. Standard errors in parentheses. z-statistics in parenthesis. Errors are clustered by action. ${ }^{+} \mathrm{p}<0.10,{ }^{*} \mathrm{p}<0.05,{ }^{* *} \mathrm{p}$ $<0.01$.

We find that settlements are more likely in the U.S., with the coefficient on the U.S. indicator variable positive and highly significant. This finding is consistent with Hypothesis 7, suggesting that the SEC has greater leverage in settlement negotiations relative to its Canadian provincial counterparts. 
We also examine the sanctions imposed in the enforcement actions. We look at four sanctions commonly imposed on defendants in insider trading actions: 1) disgorgement plus pre-judgment interest; 2) monetary penalties; 3) industry bars, which preclude serving for a specified period of time as an officer or director of a public company or serving in the financial services industry; and 4) a permanent industry bar, typically reserved for the most serious offenses. The first two variables are linear amounts, which we use as the dependent variable in OLS regressions. We code each of the enforcement actions in our sample as 1 if a bar or permanent bar is imposed for a defendant. ${ }^{99}$ We use these indicator variables as dependent variables in our last two regressions. The U.S. indicator variable is again the independent variable of interest, and we include the same control variables that we used in Tables $7 \& 8$. The regression is estimated on defendant-action-level data. We present the results in Table 9.

Table 9: Regression Analysis of Sanctions

\begin{tabular}{lcccc}
\hline \multicolumn{1}{c}{ Variable } & $\begin{array}{c}\text { Disgorgement } \\
\text { \& Interest }\end{array}$ & $\begin{array}{c}\text { Monetary } \\
\text { Penalty }\end{array}$ & $\begin{array}{c}\text { Industry } \\
\text { Bar }\end{array}$ & $\begin{array}{c}\text { Permanent } \\
\text { Bar }\end{array}$ \\
\hline US & $1.691+$ & 0.360 & $-1.971^{* *}$ & $2.210^{* *}$ \\
& $(1.67)$ & $(1.45)$ & $(-3.75)$ & $(5.52)$ \\
In(Profits) & $0.866+$ & $0.230+$ & $0.0712^{* *}$ & 0.0217 \\
& $(1.90)$ & $(1.83)$ & $(2.73)$ & $(0.76)$ \\
Tipper/ Tippee & -4.317 & -1.106 & $0.934^{* *}$ & $1.268^{* *}$ \\
& $(-1.37)$ & $(-1.50)$ & $(2.59)$ & $(3.44)$ \\
Top Insider & -0.176 & -0.413 & 0.0796 & 0.589 \\
& $(-0.06)$ & $(-0.70)$ & $(0.28)$ & $(1.58)$ \\
Fin Inst & $2.834+$ & $0.870+$ & $0.599 *$ & 0.372 \\
& $(1.75)$ & $(1.93)$ & $(1.98)$ & $(1.08)$ \\
Constant & & & & \\
& $-7.421^{*}$ & $-1.746+$ & $1.166^{*}$ & $-2.640^{* *}$ \\
\hline $\mathrm{N}$ & $(-2.08)$ & $(-1.77)$ & $(2.46)$ & $(-5.03)$ \\
\hline adj. R ${ }^{2}$ & 1021 & 1022 & 478 & 320 \\
pseudo R & 0.068 & 0.012 & & \\
\hline
\end{tabular}

99 The number of observations is smaller for these regressions because under U.S. law not all defendants would be eligible for a bar. 
Dependent variables are: 1) amount of disgorgement plus interest; 2) the amount of the monetary penalties; 3) 1 if there is an industry bar; 4) contingent upon an industry bar, coded as if there is a permanent bar. $1 \& 2$ are OLS regressions and $3 \& 4$ are logits. t-statistics and z-statistics in parentheses. Errors are clustered by action. ${ }^{+} \mathrm{p}<0.10,{ }^{*} \mathrm{p}<0.05,{ }^{* *} \mathrm{p}<0.01$.

Looking at the regressions for disgorgement and penalties, we find that disgorgement amounts are marginally greater in the U.S., but there is no significant difference in penalty amounts between the two countries, inconsistent with Hypothesis 8A. This result is not surprising given the standards used for calculating these amounts, which are quite similar in the two countries.

Turning to the regressions for industry bars, we see that Canada is more likely to apply a bar as a sanction, but if a bar is applied, the U.S. is more likely to make the bar permanent, consistent with Hypothesis 8B. Among the other independent variables, tippers or tippees are more likely than others to face an industry bar and when they do, it is more likely to be permanent. Similarly, those engaged in insider trading who are employed at a financial institution are more likely to face an industry bar.

\section{Conclusion}

Our primary contribution has been to collect and analyze original cross-border comparative data relating to insider trading enforcement. We find certain distinct differences between the two jurisdictions. To begin, U.S. investigations involve a significantly greater number of defendants and these defendants include a greater number of tippers and tippees relative to Canada. This finding is consistent with U.S. regulators having greater resources, but also with the historical inability of securities regulators in Canada to secure convictions against tippers. 100

In terms of geographical reach, Canadian securities regulators primarily concern themselves with prosecuting insider trading in Canadian companies, while the SEC is more willing to examine insider trading in companies incorporated elsewhere. This broader focus on the part of the SEC may reflect greater resources, but also a greater incidence of cross-listings in the U.S., making it likely that the insider trading occurred on a U.S. exchange, even if a company's headquarters and operations are located elsewhere.

100 See Rankin, supra note 96 and Cory and Pilkington, supra note 98. 
Regarding sanctions for insider trading, Canadian securities regulators are more likely to apply a bar as a sanction, such as banning individuals from participating in the capital markets. However, that bar is more likely to be temporary rather than permanent. The U.S. is also more likely to see settlement of insider trading cases. In Canada, our findings are consistent with Anand and Green. ${ }^{101}$ They show that settlements are less likely in insider trading, market manipulation, and fraud-related cases than in other cases such as improper trading or misuse of an exemption from the prospectus requirement.

Do these results tell us anything about the effectiveness of the centralized securities regime relied on in the U.S. relative to the more diffuse regime in Canada? To the extent that a centralized regulator has greater resources, including financial wherewithal and expertise, these resources may allow enforcers to bring more complex and extensive insider trading cases, for example, as against company executives and their advisers as well as cross-listed foreign firms. But, availability of resources is only one of many factors that affect the incidence of insider trading prosecutions; some factors are (partially) exogenous to the regulator itself, such as the number of cross-listings in a country.

Our findings do not demonstrate a need for systemic reform in either jurisdiction and they certainly do not suggest that centralized regulation necessarily provides more effective enforcement. However, they do provide insight into the differing points of regulatory emphasis in the two jurisdictions (such as foreign versus domestic companies and bars versus other types of sanctions). From a comparative perspective, our research thus allows regulators to begin to evaluate whether their enforcement approach is optimal on the basis of quantitative data. In the Canadian context, some have argued that there might be benefits to having one agency that houses both securities regulation and criminal enforcement. While our results do not definitively support the one agency position, we note that Puri, ${ }^{102}$ among

${ }^{101}$ Anita Anand \&Andrew Green, "Securities Enforcement as an Example of Crisis-driven Regulation" (2018) 55 Int Rev L \& Econ 41.

102 Poonam Puri, "A Model for Common Enforcement in Canada: The Canadian Capital Markets Enforcement Agency and the Canadian Securities Hearing Tribunal" (2008) Commissioned Reports and Studies. Paper 111, online:

$<\mathrm{http}$ :/ / digitalcommons.osgoode.yorku.ca/ cgi/ viewcontent.cgi?article=1110 \&context=reports>. 
others, has argued that while insider trading enforcement in Canada could be implemented under the current system with 13 securities regulators and a passport, a common securities regulator would be more effective.

Our research has somelimitations, of course. To begin, we have a limited number of data points on the Canadian side although we endeavored to collect the entire population for our period of study. We also do not have access to investigations in Canada so we cannot know which cases the regulators initiated but did not pursue for want of evidence, etc. A similar limitation applies to the U.S. data, as insider trading investigations may not come to light if the traded company is not brought into the investigation.

Wealso see a need for more extensive research comparing the Canadian and U.S. enforcement regimes. Insider trading reflects only a fraction of the enforcement cases brought in either jurisdiction. Moreover, it is an offense that typically focuses on individual defendants who have abused a position of trust. Fruitful comparisons could also be made of offenses more likely to be committed by institutions, such as accounting misstatements and bribery of foreign officials. We have begun to undertake empirical work in these areas, but there are other areas, such as narrative disclosures and continuing disclosure obligations that also invite further scrutiny from a comparative perspective. 